\title{
O Recife de \\ Chico Vulgo \\ e Jorge dü Peixe \\ nos passos
}

\section{do break}

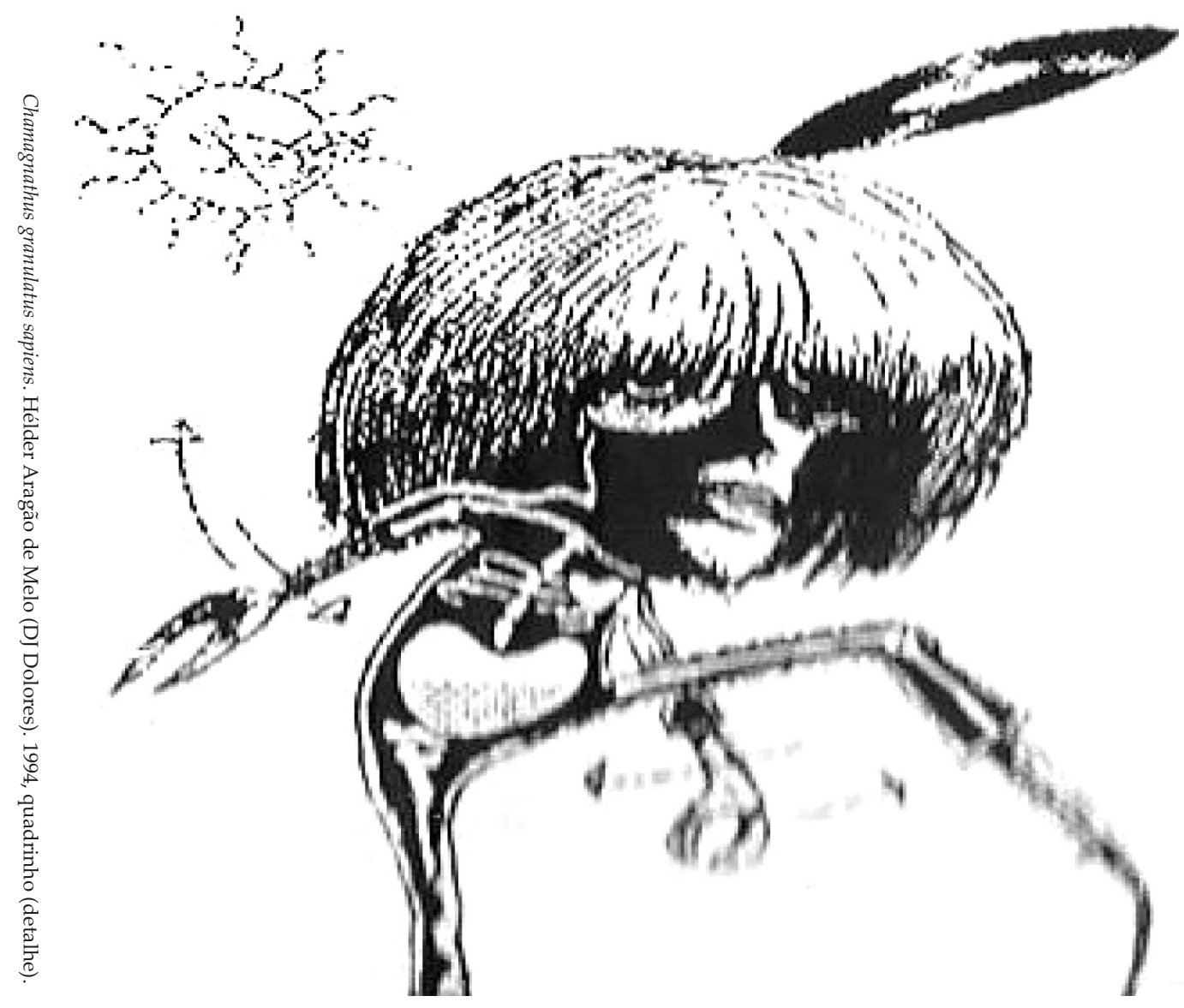

\section{Francisco Gerardo Cavalcante do Nascimento}

Mestre em História e Culturas pela Universidade Estadual do Ceará (Uece). Doutorando em História pela Universidade Federal de Uberlândia (UFU). Co-organizador do livro Nos caminhos da vida de Siqueira de Amorim. Campina Grande: EdUFCG, 2012. f26gerardo@ig.com.br 


\section{O Recife de Chico Vulgo e Jorge dü Peixe nos passos do break}

Chico Vulgo and Jorge dü Peixe's Recife alongbreak steps

Francisco Gerardo Cavalcante do Nascimento

${ }^{1}$ CALVINO, Ítalo. As cidades invisíveis. São Paulo: Companhia das Letras, 1990, p. 30.

2 "As disputas que incidem sobre essas demarcações socioespaciais urbanas podem resultar tanto em um enfrentamento político mais elaborado quanto na mera contraposição de estilos de vida, marcadas pelas formas cotidianas de ritualizar códigos de conduta". LEITE, Rogério Proença. Contrausos e espaço público: notas sobre a construção social dos lugares na Manguetown. Revista Brasileira de Ciências Sociais, v. 17, n. 49, fev. 2002, p. 130.

${ }^{3}$ Virgínia Pontual realiza um apanhado de alguns eventos históricos de caráter político e econômico do Recife que remonta ao período colonial, à dominação holandesa, e confere ênfase às décadas de 1930 e 1950, nas quais, para a autora, se definiu a "tessitura cultural" que compõe a cidade. Ela menciona, então, as construções do sistema de canais, o Jardim Botânico, as pontes, o Palácio da Boa Vista, tidos como "empreendimentos urbanísticos" que respaldariam a representação de "cidade da liberdade", animada por um sentimento de ufanismo, destemor e audácia, em contraposição à natureza "exótica" característica do Brasil colonial. PONTUAL, Virgínia. Tempos do Recife: representações culturais e configurações urbanas. Revista Brasileira de História, $\mathrm{v}$. 21, n. 42, São Paulo, 2001.
RESUMO

Neste artigo o debate se centra no Recife da década de 1980, entendido não apenas como a urbe que serviu de palco e cenário para o MangueBit, mas como um espaço coletivo múltiplo que vivenciou a atmosfera política do pósditadura militar. No universo citadino recifense buscaremos captar a aventura da convivência e da produção cultural de certas parcelas dos jovens. Diante disso, encararemos dois desafios. $\mathrm{O}$ primeiro consistirá em situar Chico Vulgo e Jorge dü Peixe imersos em uma grupalidade juvenil pautada no movimento hip hop. O segundo implicará a necessidade de traçar as trilhas básicas das cartografias culturais do Recife segundo as representações dos breakers. PALAVRAS-CHAVE: Recife: anos 1980: breakers; Chico Vulgo e Jorge dü Peixe.

\begin{abstract}
This discussion focuses on 1980's Recife understood not only as the stage and background for MangueBit music but also as a multiple collective space experiencing the post-military dictatorship political atmosphere. We capture certain youth groups' adventure of togetherness and cultural production in the local urban universe. Two challenges arise. The first one is situating Chico Vulgo and Jorge düPeixe in a hip hop-based youth group. The second one requires tracing the basic tracks of Recife's cultural cartography according to breakers' representations.
\end{abstract}

KEYWORDS: Recife 80's: breakers; Chico Vulgo and Jorge dü Peixe.

Em certas horas, em certas ruas, surge a suspeita de que ali há algo de inconfundível, de raro, talvez até de magnifico; sente-se o desejo de descobrir o que é, mas tudo o que se disse sobre Aglaura até agora aprisiona as palavras e obriga a rir em vez de falar. ${ }^{1}$

A Aglaura dos contos de Calvino, em certa medida, remete-nos ao Recife no qual nos deteremos nas próximas páginas. Afinal, transitar por essa cidade nos descerra um cenário impressionante que, para além das semelhanças com outras capitais brasileiras, revela traços marcantes nos corpos que o habitam e o permeiam de sons, cores, cheiros e sentidos. Daí que a epígrafe de Calvino aponta para as possibilidades de análises da urbe como um admirável conjunto esculpido por mãos humanas, local de disputas e de "confrontos políticos" ${ }^{2}$ em que a comunicação de diferentes grupos sociais apresenta distinções e variações, haja vista que os diferentes ajuntamentos que a compõem fazem apropriações distintas desse espaço. Nesse sentido, podemos falar em peculiaridades de uma cidade quando observamos os "usos e contrausos" dos seus habitantes, sem nos atermos 
apenas às suas ruas, praças, esquinas, comércios, ou mesmo políticas governamentais e ações da iniciativa privada.

Recife seria uma cidade que teima em ser moderna, se considerados alguns aspectos históricos que a elevaram à denominação de "metrópole do Nordeste", segundo uma concepção exagerada de que nela o secular sucumbe à novidade, desde os remotos anos de colonização europeia ${ }^{3}$ até sua primeira reforma urbanística em 1910. A apropriação da natureza foi, assim, como argumenta Pontual, embalada pela quimera de representações de um desenvolvimento ordenado ditado por planejamentos e diretrizes urbanísticas. ${ }^{4}$ Sobretudo a partir dos anos 1960 e 1970, assistiu-se à consolidação de uma cidade "tentacular", em que a mancha urbana espraiou-se para áreas ao sul da capital, momento em que bairros e subúrbios expandiram-se de forma exponencial, alcançando até a Grande Região Metropolitana, principalmente Olinda, Jaboatão dos Guararapes e Camaragibe.

A "metrópole do Nordeste", na década de 1980, continuava a crescer na direção dos subúrbios. ${ }^{5}$ A taxa de crescimento populacional, motivada por uma ocupação urbana desordenada, chegou aos mais longínquos bairros das cidades da Região Metropolitana. A capital, desde os imemoriais tempos coloniais da Guerra dos Mascates, ostentava seu posto de chamariz ou reduto para o comércio, e a população interiorana arriscava tudo por uma chance na urbe dos mangues.

A ocupação de áreas não centrais vem desde os anos 1930 e acelerouse nas décadas seguintes, tendo seu ápice entre 1960 a 1980, quando ocorreu um intenso processo de urbanização e consequente periferização ${ }^{6}$ do Recife. E esse fenômeno prosseguiu, pois "a cidade não para, a cidade só cresce", como versou Chico Science na composição "A cidade". ${ }^{7}$ Nas periferias do Grande Recife foram fecundados nossos sujeitos históricos. São elas os locais de origem do movimento hip hop do Recife e municípios vizinhos, que formaram uma grande teia cultural que emana das adjacências e torna-se visível no centro.

Seja em que lugar for do Grande Recife, no entanto, nele se descortina o triste espetáculo da proliferação de moradias insalubres, a falta de serviços básicos de saúde, educação, saneamento, além da fome onipresente nos casebres espalhados pelos rios Beberibe, Tejipió e Capibaribe. Aí padece uma massa humana que ficou relegada à margem do "progresso" e que, desde épocas passadas, teve sua situação exposta de forma contundente pelo geógrafo Josué de Castro.

\section{Geografia da fome e do passo: uma periferia que quebra e dança}

O título do livro mais célebre de Josué de Castro, Geografia da fome ${ }^{8}$, fornece, a nosso ver, todo um sentido para o hip hop ${ }^{9}$ ao tratar do Grande Recife e sua apropriação por uma parcela dos jovens recifenses. Sem resignar-se ante supostos determinismos geográficos, ele sublinhou que os problemas sociais não são determinados pelo espaço que as pessoas habitam, mas por sistemas econômicos e sociais, independentemente de condições climáticas, sejam elas do semiárido ou mesmo a Zona da Mata, configurando-se, portanto, como questões de um Nordeste brasileiro imerso em profundos e seculares ranços coloniais.

Mas o namoro entre o autor e a poesia urbana e contemporânea de Chico Science foi mais evidente e profícuo no caso do romance Homens e caranguejos $^{\mathbf{1 0}}$, de 1966, que descreve o cotidiano de uma comunidade ribeiri-
${ }^{4}$ Cf. idem, Uma cidade e dois prefeitos: narrativas do Recife das décadas de 1930 a 1950. Recife: Editora Universitária da UFPE, 2001.

${ }^{5}$ Segundo Virgínia Pontual, o crescimento demográfico do Recife entre 1940-1950 e 19501960 foi respectivamente, de $50,6 \%$ e $51,9 \%$. Idem, Tempos do Recife, op. cit.

${ }^{6}$ Tomamos o termo periferização como uma constatação dos processos intensos de urbanização verificados no Brasil nas últimas seis décadas. Isso, evidentemente, é resultado de um desenvolvimento econômicosocial desigual que converte a periferia em habitat do exército de reserva que sustenta o modelo econômico vigente. Cf. BORGES, William Antônio e ROCHA, Márcio Mendes. A compreensão do processo de periferização urbana no Brasil por meio da mobilidade centrada no trabalho. Geografia, v. 29, n. 3, Rio Claro, set.- dez. 2004.

7 "A cidade" (Chico Science), Chico Science \& Nação Zumbi. CD Da lama ao caos. Chaos/ Sony, 1994.

${ }^{8}$ CASTRO, Josué de. Geografia da fome - o dilema brasileiro: pão ou aço. 14. ed. Rio de Janeiro: Civilização Brasileira, 2001.

${ }^{9}$ Lembramos que há certo consenso entre os especialistas em hip hop quanto à origem do termo. Como explicam Rocha, Domenich e Casseano, "o termo hip hop, que significa, numa tradução literal, movimentar os quadris (to hip, em inglês) e saltar (to hop), foi criado pelo DJ Afrikaa Bambaataa, em 1968, para nomear os encontros dos dançarinos de break, DJs (disc-jóqueis) e MCs (mestres de cerimônias) nas festas de rua no bairro do Bronx, em Nova York. Bambaataa percebeu que a dança seria uma forma eficiente e pacífica de expressar os sentimentos de revolta $\mathrm{e}$ de exclusão, uma maneira de diminuir as brigas de gangues do gueto e, consequentemente, o clima de violência". ROCHA, Janaína, DOMENICH, Mirella e CASSEANO, Patrícia. Hip Hop: a periferia grita. São Paulo: Perseu Abramo, 2001, p. 17.

${ }^{10}$ CASTRO, Josué de. Homense caranguejos. 4. ed. Rio de Janeiro: Civilização Brasileira, 2010. 
11 Ver o Manifesto surrealista, de 1924. In: BRETON, André. Manifestos do surrealismo. São Paulo: Brasiliense, 1985

${ }^{12}$ Disponível em <http://enciclopedia.itaucultural.org. br/pessoa21706/abelardo-dahora $>$.

${ }^{13}$ CASTRO, Josué de. Homens e caranguejos, op. cit., p. 10 e 11 .

${ }^{14}$ Figura antropozoomórfica concebida pelo DJ e designer gráfico Hélder Aragão de Melo (DJ Dolores), contida no encarte do CD Da lama ao caos, op. cit. A gravura simboliza um ser humano habitante de Recife que, após ingerir cerveja feita com água da baba de um caranguejo mutante radioativo, adquiriu essa forma. Porém, ela remete, propositalmente, ao caboclo de lança (figura principal do maracatu rural pernambucano), com sua volumosa cabeleira de ráfia colorida.

${ }^{15}$ Caranguejos com cérebro foi um release sobre a cena musical que estava despontando em Recife, escrito por Fred 04 e Renato L em 1991 e publicado neste mesmo ano na imprensa pernambucana e no encarte do CD Da lama ao caos, op. cit. A imprensa local o identificou como um manifesto, daí ele ter ficado conhecido como Manifesto caranguejos com cérebro.

16 "A cidade", op. cit.

17 IBGE. Sinopse do Censo Demográfico Brasileiro de 2010. Disponível em <https://censo2010.ibge.gov.br/sinopse/ index.php? $\mathrm{uf}=26 \&$ dados $=1>$. Acesso em 12 maio 2016.

${ }^{18}$ Esse documento condensa uma leitura social das mortes violentas de jovens brasileiros conforme a Base de Dados Nacional do Sistema de Informações da Mortalidade (SIM), do Datasus, do Ministério da Saúde, para as faixas etárias de 15 a 24 anos e para o conjunto da população. O Mapa da violência IV utiliza dados de 1993 a 2002. Disponível em $<$ http://www.unesco.org/new/ pt/brasilia/about-this-office/ unesco-resources-in-brazil/ studies-and-evaluations/violence/violence-map/>. Acesso em 10 maio 2016. nha do bairro de Afogados, no Recife, ainda na primeira metade do século XX. Guardando as devidas proporções literárias, continentais, temáticas e artísticas, seria possível estabelecer uma comparação entre a importância do "Manifesto surrealista"11, de André Breton, para o surrealismo e a obra de Josué de Castro para o MangueBit, produções seminais em seu campo e no seu tempo. Homens e caranguejos escancara a fome do povo ribeirinho saciada com caranguejos, suas moradias construídas com restos de madeira, palhas, massapé, às margens do Capibaribe. Essa situação foi retratada por artistas que deram uma face aos ribeirinhos, como Abelardo da Hora, em sua série Meninos do Recife. ${ }^{12}$

Há uma poética visceral em Josué de Castro. Nela sobressai a simbiose entre homem e natureza reveladora da antropomorfização do mangue, do qual brotam "seres humanos feitos de carne de caranguejo, pensando e sentindo como caranguejos". ${ }^{13}$ Nessa relação se instalam a degradação e a coexistência de dependência por parte do ser humano e de descaracterização do ambiente natural.

A cidade das figuras de Josué de Castro, que vão além da imaginação, habitavam também o imaginário de Chico Science. A leitura da produção do geógrafo potencializou, com base na música, a representação do homem caranguejo como alguém não apenas faminto de alimentos, como também de cultura. Adereços de manifestações populares culturais foram adicionados ao homem caranguejo de Josué de Castro, com a diversão levada a sério, como o próprio Chico Science preconizou.

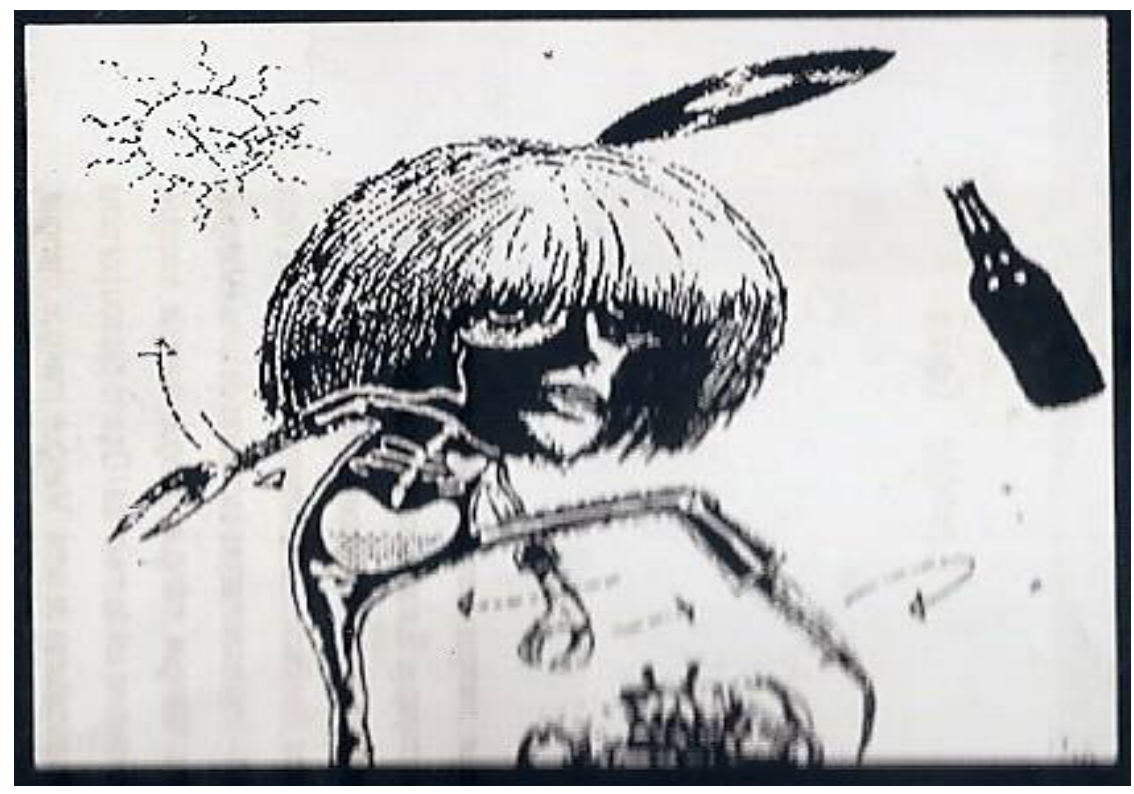

Figura 1. Chamagnathus granulatus sapiens. ${ }^{14}$ Hélder Aragão de Melo (DJ Dolores). 1994, quadrinho (detalhe).

As relações entre Homens e caranguejos e o MangueBit perpassam igualmente o "Manifesto caranguejos com cérebro". ${ }^{15}$ No caso de Castro, ele defende uma revolução que tome a cidade das mãos dos ricos, dos poderosos e dos políticos hipócritas e ladrões; já no manifesto-release, os autores Fred 04 e Renato L propõem tomar a cidade de assalto a partir da música ou, como eles mesmos escreveram, "basta injetar um pouco de energia na lama". Nessa empreitada emergem, então, temas como conflitos étnicos, midiotia, sexo não virtual e personagens da cultura local e global como Josué de Castro, Jackson do Pandeiro, Malcom Maclaren e os Simpsons. 
Estas ponderações acerca do Recife servem para refletirmos sobre de qual cidade falamos, seja a das entranhas podres expostas por Josué de Castro, a descrita pelos jornalistas Fred 04 e Renato L ou a capital cantada em verso e prosa por Chico Science, em que prédios, homens, transporte coletivo, velocidade, fedentina e a noção cínica de progresso disputam o mesmo espaço na urbe:

O sol nasce e ilumina as pedras evoluídas/ que cresceram com a força de pedreiros suicidas/ cavaleiros circulam vigiando as pessoas/ não importa se são ruins, nem importa se são boas/ e a cidade se apresenta centro das ambições/ para mendigos ou ricos e outras armações/ coletivos, automóveis, motos e metrôs/ trabalhadores, patrões, policiais, camelôs/ a cidade não para, a cidade só cresce lo de cima sobe e o de baixo descel a cidade se encontra prostituídal por aqueles que a usaram em busca de saídal ilusora de pessoas de outros lugares/ a cidade e sua fama vai além dos mares/ no meio da esperteza internacional/ a cidade até que não está tão mal/ e a situação sempre mais ou menos/ sempre um com mais e outros com menos/ eu vou fazer uma embolada, um samba, um maracatul tudo bem envenenado, bom pra mim e bom pra tul pra gente sair da lama e enfrentar os urubu/ num dia de sol Recife acordou/ com a mesma fedentina do dia anterior. ${ }^{16}$

O cotidiano daqueles que migraram para o Recife engrossou o caudaloso contingente humano dos miseráveis que abarrotam a metrópole, que em sua maioria são a mão de obra barata e farta que abunda das periferias para o centro e regiões mais nobres, carregando tecidos, cestos de frutas, verduras, importados de baixa qualidade e, por que não dizer, a própria cidade nos ombros. Essa é a cidade do Recife, cujo cinturão periférico estrangula a urbe, com uma população predominantemente jovem entre 15 e 30 anos, segundo o IBGE ${ }^{17}$, em que o índice de mortalidade no Mapa da violência $I^{18}$, produzido pela Unesco, exibe números alarmantes da taxa de homicídios nessa faixa da população.

\section{Grupos juvenis: o pertencimento conflitivo de jovens na metrópole recifense}

Em nosso trabalho nos valeremos da noção de juventude, em torno da qual - como, de resto, de quase tudo o mais - não existe, é claro, um entendimento comum a todos quantos procuram defini-la. Afinal, o nosso objeto de pesquisa se relaciona a um conjunto de jovens do Recife da década de 1980, uma "cidade globalizada". ${ }^{19}$

Nesse contexto, uma questão importante se coloca: o que é ser jovem ${ }^{20}$ e qual seu suposto papel ou função social? Qualquer que seja a resposta a estas indagações, importa, como ponto de partida, contextualizar a abordagem sobre a juventude e tratar tal categoria como "uma construção social e cultural" ${ }^{21}$, passível de variações de acordo com o tempo e o lugar a que se refira. ${ }^{22}$

Sob essa ótica, os jovens não devem ser tomados em "termos absolutos e abstratos", enquadrados em "classificações genéricas" com base em "uma imagem esquemática proposta como definição", pois "erigida e nomeada a partir daí, tal realidade impede que se construam e reconstruam sujeitos sociais historicamente diversos, com trajetórias diferenciadas, como grupos e indivíduos que participam da delimitação de um campo como protagonistas em movimento". ${ }^{23}$
${ }^{19}$ Nela se expressa um ambiente "glocal", que evidencia a articulação entre o global e o local. García-Canclini sugere que o palco privilegiado do processo de glocalização seria a cidade: "Além da cidade histórica e da cidade industrial, existe a cidade globalizada, que se conecta com as redes mundiais da economia, finanças e comunicações". GARCÍACANCLINI, Néstor. Glocalize: o local globalizado. In: Consumidores e cidadãos: conflitos multiculturais da globalização. Rio de Janeiro: Editora UFRJ, 1999, p. 109

${ }^{20}$ A complexidade da questão transparece nas observações formuladas por Helena Abramo: "a noção de juventude é socialmente variável. A definição do tempo de duração, dos conteúdos e significados sociais desses processos modifica-se de sociedade para sociedade e, na mesma sociedade, ao longo do tempo e através das suas divisões internas. Além disso, é somente em algumas formações sociais que a juventude se configura como um período destacado, ou seja, aparece como uma categoria com visibilidade social". ABRAMO, Helena Wendel. Cenas juvenis: punks e darks no espetáculo urbano. São Paulo: Página Aberta, 1994, p. 1.

${ }^{21}$ LEVI, Giovanni e SCHMITT, Jean-Claude (orgs.). História dos jovens: da antiguidade à era moderna, v. 1. São Paulo: Companhia das Letras, 1996, p. 8.

${ }^{22}$ De mais a mais, como analisa Hobsbawm, a juventude que identificamos como faixa etária é, na realidade, uma elaboração do pós-Segunda Guerra em determinadas circunstâncias históricas. Cf. HOBSBAWM, Eric. Revolução cultural. In: Era dos extremos: o breve século XX (1914-1991) São Paulo: Companhia das Letras, 1994. 
23 ALVIM, Rosilene e GOUVEIA, Patrícia (orgs.). Juventude anos 90. Rio de Janeiro: Contra Capa, 2000, p. 14.

${ }^{24}$ MARGULIS, Mario. Juventud: uma aproximación conceptual. In: BURAK, Solum Donas. Adolescencia y juventude en América Latina. Cartago: Libro Universitário Regional, 2001, p. 42

${ }^{25}$ MAFFESOLI, Michel. O tempo das tribos: o declínio do individualismo nas sociedades de massa. Rio de Janeiro: Forense Universitária, 1987, p.124

${ }^{26}$ BURAK, Solum Donas. Adolescencia y juventud: viejos y nuevos desafios en los albores del nuevo milênio. In: BURAK, Solum Donas (org.), op. cit., p. 27

27 DAMASCENO, Francisco José Gomes. Sutil diferença: o movimento punk e o movimento hip hop em Fortaleza - grupos mistos no universo citadino contemporâneo. Tese (Doutorado em História) - PUC-SP, São Paulo, 2004, p. 39.

${ }^{28}$ ALVES, Adjair. O rap é uma guerra e eu sou o gladiador: um estudo etnográfico sobre as práticas sociais dos jovens hoperes e suas representações sobre a violência e a criminalidade. Tese (Doutorado em Antropologia) - UFPE, Recife, 2008

${ }^{29}$ Pensada nesses termos, a política, como sustenta Paranhos, transpõe a barreira dos marcos meramente institucionais que a vinculam ao Estado. Ela se inscreve nas relações de poder que se manifestam onde quer que se estabeleçam relações sociais. Cf. PARANHOS, Adalberto. Política e cotidiano: as mil e uma faces do poder. In: MARCELLINO, Nelson C. Introdução às Ciências Sociais. 17. ed. Campinas: Papirus, 2010.

30 SHUSTERMAN, Richard. Vivendo a arte: o pensamento pragmatista e a estética popular. São Paulo: Editora 34, 1998, p. 207.
Vem daí que, a rigor, não existe uma única juventude, mas representações diversificadas elaboradas sobre os indivíduos com faixas etárias identificadas entre o início da puberdade e a fase adulta:

No existe una única juventud: em la ciudad moderna las juventudes son múltiples, variando em relación con características de clase, el lugar donde viven y la generación a que pertenecen $y$, además, la diversidad, el pluralismo, el estallido cultural de los últimos años se manifiestan privilegiadamente entre los jóvenes que ofrecen um panorama sumamente variado y móvil que abarca sus comportamientos, referencias identitarias, lenguajes y formas de sociabilidad. ${ }^{24}$

No que nos diz respeito mais de perto, interessa-nos direcionar o olhar para jovens pertencentes a grupos recifenses marginalizados socialmente, situados no mundo periférico ou suburbano, dotado de poucos atrativos culturais e educacionais, no qual pulsa o hip hop. Nossa atenção se concentrará nas iniciativas pontuais de jovens da periferia do Grande Recife, que, com um estilo de vida pautado na música, buscaram a visibilidade perante a sociedade, como que disputando seu lugar nos espaços públicos e influindo, assim, na conformação espacial da cidade. Nessa linha de raciocínio, como assinala Maffesoli, "a sociedade [...] não se resume numa mecanicidade racional qualquer; ela vive e se organiza, no sentido estrito do termo, através de reencontros, das situações, das experiências no seio dos diversos grupos". ${ }^{25}$

Por essa via, criou-se no imaginário juvenil um sentimento de pertencimento ao meio urbano com o fazer artístico. Os envolvidos nessas ações passaram, como decorrência disso, a existir culturalmente, rompendo com sua invisibilidade ante a indiferença do poder público. E, nessa caminhada, eles foram na contramão da marcha "natural" das coisas, cujo quadro dominante é bem exposto por Solum Donas Burak:

Cabe destacar en el ámbito cultural el poço acceso que tienen los adolescentes y jóvenes en general a actividades culturales (cine, teatro, danza, museos, etc.) en parte por su escasa formación em elgusto y apreciacióndel arte, como por el costo de tener acceso a los mismos, y por las distancias geográficas que existen para un alto porcentajedel grupo para ir a los centros urbanos donde se dan este tipo de manifestaciones. El otro polo es el escasso acceso a manifestar se culturalmente nuevamente debido a la carencia de opciones de centros de enseñanza de artes y los escasos recursos económicos para poder expresar sus necesidades y habilidades creativas en este campo. ${ }^{26}$

Por outras palavras, a questão aqui apresentada remete à forma como grupos de jovens (breakers em particular) se "espetacularizaram" na sociedade para serem percebidos, quiçá admirados e compreendidos. Objetivamente, eles puseram em prática uma política afirmativa de pertencimento combativo, que deu lastro à luta pela apropriação dos espaços públicos e/ou por um não alinhamento às políticas governamentais de controle social. Entraram, pois, em cena jovens periféricos, imbuídos do sentimento de coletividade, ou, como Damasceno apontou, ao se referir ao movimento punk de Fortaleza nas décadas de 1970 e 1980, "aos poucos os pequenos grupos se formavam e até as primeiras bandas estavam formadas; era o início da trajetória desta coletividade, que passaria a se autodenominar movimento" ${ }^{27}$ 
Isso não representa uma novidade. A forma como os jovens são vistos no mundo contemporâneo tem suas origens nos grupos juvenis com atuação voltada ao universo da cultura, o que atraiu holofotes para as suas ações e aumentou as chances de agrupamentos congêneres transitarem pela urbe e suas distintas esferas. A primeira batalha travada consistiu na desconstrução da ideia de negatividade que circunda o elemento jovem. Começou a ganhar força o entendimento, segundo Adjair Alves ${ }^{28}$, de que há um caráter político ${ }^{29}$ nas suas ações, concepção que alimentou, então, um sentimento de positividade.

Por esse prisma, a relação que se dá dentro das gangues - quaisquer que sejam os problemas internos que elas vivenciam - desde os primórdios do hip hop até os dias atuais, indica a presença de parceria, confiança, laços afetivos, pois, nesse contexto, "ética e estética tornam-se um só; e o produto de uma vida ética torna-se um exercício de viver esteticamente" ${ }^{30}$ De acordo com Tricia Rose ${ }^{31}$, isso abre caminho para a formação de uma identidade pelos jovens, mediante a constituição de grupalidades em que, entre outros sentimentos (que, acrescentamos, não excluem, obviamente, as disputas, os ciúmes, as lutas), se exprime também a afeição entre os pares.

De fato, o movimento hip hop, desde seu surgimento até hoje, demonstrou que a relação entre juventude e crítica social passa pela desconstrução do que seja convencional e opressor e valoriza a participação ativa ou uma ideia de cooperação cultural entre os seus praticantes. Daí que, para eles, "ser cidadão não tem a ver apenas com direitos reconhecidos pelos aparelhos estatais para os que nasceram em um território, mas também com as práticas sociais e culturais que dão sentido de pertencimento, e fazem com que se sintam diferentes os que possuem uma mesma língua, formas semelhantes de organização e de satisfação das necessidades". ${ }^{32}$

Em meio a isso, é significativo atentarmos para uma das formas que os jovens dos grupos de hip hop que estudamos adotam como meio de afirmação de sua visibilidade: os modos como circulam pela cidade ou pela região que habitam. Se, de início, eles desataram processos espontâneos de visibilização, num segundo momento decorreram de uma construção contínua e eficaz de uma maneira de se dar a conhecer como produto de uma rede de sociabilidades entre os jovens praticantes do hip hop. Esta, como nos relatou Zé Brown, é fundamental: "a comunidade tem uma solidariedade que é dela mesma. As pessoas se ajudam, velho, porque, do contrário, complica ainda mais pra todo mundo. A moçada sabe quem é quem dentro da comunidade". ${ }^{33}$

Aliás, circular aleatoriamente pela cidade em diversos pontos foi uma saída encontrada pelos breakers para desnortear as forças policiais mobilizadas em ações de repressão: "passávamos um bom tempo carregando som, piso pra dançar, íamos da Rua do Hospício pro Parque 13 de Maio, em frente à Biblioteca Pública, depois voltávamos pro Hamburgão". ${ }^{34}$ Como era de se esperar, não foi isenta de conflitos a conversão de certos espaços públicos em "pedaços" do break. Nesses casos, como é sabido, travam-se lutas de dimensões variadas, envolvendo componentes raciais e de classe social. Em poucas palavras, "o conflito, a hostilidade estão sempre latentes". ${ }^{35}$

A despeito de operarem em circunstâncias adversas, os grupos abarcados nesta pesquisa lograram, à sua moda, se apropriar da cultura e se projetar $^{36}$, à semelhança de outras experiências verificadas anteriormente por outros pesquisadores em outras regiões metropolitanas. "Posso sair daqui para me organizar". ${ }^{37}$ Esta afirmação de Chico Science funcionou como
31 Tricia Rose argumenta que "a cultura hip hop emergiu como fonte de formação de uma identidade alternativa e de status social para jovens numa comunidade, cujas antigas instituições locais de apoio foram destruídas, bem como outros setores importantes. A identidade do hip hop está profundamente arraigada à experiência local e específica e ao apego de um status em um grupo local ou família alternativa. Esses grupos formam um novo tipo de família, forjada a partir de um vínculo intercultural que, a exemplo das formações das gangues, promovem isolamento e segurança em um ambiente complexo e inflexível". ROSE, Tricia. Um estilo que ninguém segura: política, estilo e a cidade pós-industrial no hip-hop. In: HERSCHMANN, Micael (org.). Abalando os anos 90: punk e hip-hop - globalização, violência e estilo cultural. Rio de Janeiro: Rocco, 1997, p. 202.

${ }^{32}$ GARCÍA-CANCLINI, Néstor. Consumidores e cidadãos, op . cit., p. 46.

33 Entrevista concedida por Zé Brown a este pesquisador no Recife em 10 fev. 2012. Zé Brown é rapper, arte- educador e cabeleireiro. Durante alguns anos foi vocalista da banda de rap Faces do Subúrbio. Atualmente apresenta-se em carreira solo. A comunidade citada por ele é do Morro do Alto Zé do Pinho.

${ }^{34}$ Entrevista concedida por Fábio de Morais Luna (DJ Spider) a este pesquisador no Recife em 10 jan. 2015.

${ }^{35}$ MAGNANI, José Guilherme Cantor. Festa no pedaço: cultura popular e lazer na cidade. São Paulo: Brasiliense, 1984, p. 139.

${ }^{36}$ Projetar-se, aqui, não remete necessariamente a algum reconhecimento midiático. Como anotou Damasceno, “estas inúmeras formas de se encontrarem, de treinarem e se prepararem para dançar com maestria, desaguavam nos bailes realizados nos finais de semana. Neles as gangues em processo de criação se consolidavam em uma espécie de reconhecimento dos pares entre si, mas, sobretudo, dos jovens de cada um destes bairros. Eles se tornavam conhecidos e respeitados". DAMASCENO, Francisco José Gomes, op. cit., p. 62. 
${ }^{37}$ Palavras contidas na canção "Da lama ao caos" (Chico Science), Chico Science \& Nação Zumbi. CD Da lama ao caos, op. cit.

${ }^{38}$ COELHO, Teixeira. O que é ação cultural? São Paulo: Brasiliense, 1989, p. 16.

${ }^{39}$ TELES, José. Do frevo ao manguebeat. São Paulo: Editora 34, 2000, p. 225.

${ }^{40}$ Entrevista concedida por Renato $\mathrm{L}$ a este pesquisador no Recife em 18 jan. 2006.

${ }^{41}$ Expressão utilizada pelo jornalista e crítico musical Arthur Dapieve em sua obra homônima. DAPIEVE, Arthur. BRock: o rock brasileiro dos anos 80 . São Paulo: Editora 34, 1995

${ }^{42}$ Entre os artistas "regionalizados" estavam Abdias, Reginaldo Rossi, Moreira da Silva, Raul de Barros. Informação disponível em<http://www. toque-musicall.com/?cat $=334>$. Acesso em 22 fev. 2017. se fosse uma palavra de ordem, uma conclamação a favor do investimento de energia para a legitimação dos jovens da periferia como protagonistas do movimento hip hop.

Trilhando esse caminho, a convergência em torno de uma coletividade faz as vezes de porta de entrada da juventude contemporânea na produção e consumo de bens culturais. A exemplo do que se deu com jovens recifenses, o exercício da produção de ações culturais tornou-se uma constante em suas vidas. Trocando em miúdos, "o agente cultural é, aqui, um animador, é dele que parte a ação nessa terminologia teológica, é ele o criador". ${ }^{38}$

Em outros termos, aqueles jovens (pobres, na sua maioria) de Camaragibe, Jaboatão dos Guararapes, Olinda e do Recife, necessitavam movimentar-se culturalmente, ainda que, no início dos anos 1980, a movimentação no mundo do hip hop, em especial o break, possuísse todas as características de um arranjo amador de jovens, desorganizado e espraiado pela região metropolitana da capital de Pernambuco.

\section{A década de 1980: quando o mundo suburbano se agita}

Tendo em vista o recorte temporal deste trabalho, é imprescindível apresentarmos um quadro panorâmico da cena musical recifense da década de 1980. No livro Do frevo ao manguebeat, José Teles destacou que os anos 80 em Pernambuco podem ser definidos como "anos perdidos" ${ }^{39}$, visão semelhante à do jornalista e artífice do MangueBit Renato L: "Quem viveu no Recife nos anos 80 [...] viveu uma época morta, em termos de cultura. Não aconteceu nada aqui no Recife nos anos 80, ou aconteceu muito pouco também na área de cinema [...] na área de música só se tinha Alceu Valença, na minha opinião, já completamente estagnado; a produção dele já completamente estagnada. Então Recife passou batido pelo rock brasileiro dos anos $80^{\prime \prime} .{ }^{40}$

Para Teles, Renato L e outros que suspiram de saudades de outro tempo, a década mais fértil para a música pernambucana, inclusive sob a perspectiva da projeção nacional alcançada, seria, certamente, a de 1970 com Alceu Valença, Ivinho, Flaviola, Ave Sangria, Geraldo Azevedo, Quinteto Violado, vários deles artistas que alavancaram suas carreiras por todo o Brasil e até no exterior, se apresentado em festivais como o de jazz de Montreux, na Suíça (caso, por exemplo, de Ivinho, em 1978). E quando os anos 1980 se abriram para o rock, tanto Teles quanto Renato L ressaltam que Pernambuco ficou à margem no momento em que o mainstream musical do BRock ${ }^{41}$ estava direcionado para o Rio de Janeiro, Brasília, Porto Alegre e São Paulo, com grupos como Paralamas do Sucesso, Legião Urbana, Blitz, Plebe Rude, Camisa de Vênus, Engenheiros do Hawai e Nenhum de Nós. É importante assinalar que o restante do país não abocanhou essa generosa fatia do mercado fonográfico constituído pelo rock nacional, mantendo-se restrito a iniciativas pontuais de algumas gravadoras multinacionais que lançaram selos regionais para artistas do Norte e Nordeste, em particular a EMI-Odeon, que criou o selo "Jangada", impulsionado por artistas considerados regionalizados ${ }^{42}$, não aptos, segundo a empresa, para terem circulação mais ampla.

Seja como for, não se deve deixar de reconhecer que, na década de 1980, diversos segmentos da cultura de Pernambuco mostraram-se ativos no mínimo a partir de iniciativas pessoais, como as de Fred 04 e do próprio Renato L. Formaram-se bandas punks, como Trapaça e Serviço Sujo, a de 
Fred 04, que mais adiante fundaria a Mundo Livre S/A, e Sala 101, de Renato L. Este futuramente realizaria, como trabalho de conclusão de curso de Jornalismo na Universidade Federal de Pernambuco (UFPE), o programa Décadas, na Rádio Universitária, que viria a ser um meio de propagação da "boa música", como os próprios Renato L e Fred 04 denominavam o que nele era executado: "A orientação básica do programa seria a de veicular todo um conjunto de músicas que não tocavam nas demais rádios, por não terem sido ainda incluídas no cast das grandes gravadoras nacionais de onde provinha praticamente toda a programação das principais FMs do país" ${ }^{43}$

Por essa época, em outra parte do Grande Recife, mais precisamente em Rio Doce, periferia de Olinda, alguns jovens ensaiavam passos de break. Lá, Chico Vulgo, que mais tarde seria conhecido por Chico Science, e Jorge dü Peixe, faziam parte da Legião Hip Hop, um dos muitos grupelhos juvenis existentes na primeira metade dos anos 1980 na Região Metropolitana do Recife, também denominados "gangues de dança de rua", inspiradas nos bboys norte-americanos. Paralelamente, outras experiências sonoras de Chico e Jorge devem ser destacadas, como o Loustal, o Orla Orbe, com influências diretas do funk, soul e hip hop, e, principalmente, o Bom Tom Rádio, uma espécie de laboratório musical em que ambos, mais o jovem José Carlos Arcoverde (Mabuse), concebiam experimentações sonoras de forma amadora, mas que serviram de base para músicas como "Samba de lado" 44 e a já citada "A cidade".

Essa pré-catarse cultural, discutida por Ribeiro ${ }^{45}$ em sua dissertação de Mestrado, refletia o potencial latente nessa parcela da juventude, com seus focos espalhados pela malha metropolitana da cidade do Recife, usina criativa de ações culturais que comporiam toda a cena que emergiria na década seguinte. Vivia-se um ambiente de muitas bandas, embora com pouca ou nenhuma repercussão na imprensa local, com jovens músicos imersos na distopia. Nos anos 1980 os espaços das páginas culturais eram reservados acima de tudo a astros musicais surgidos nas décadas anteriores ou ao novo BRock sudestino, como, por exemplo, aos Titãs.

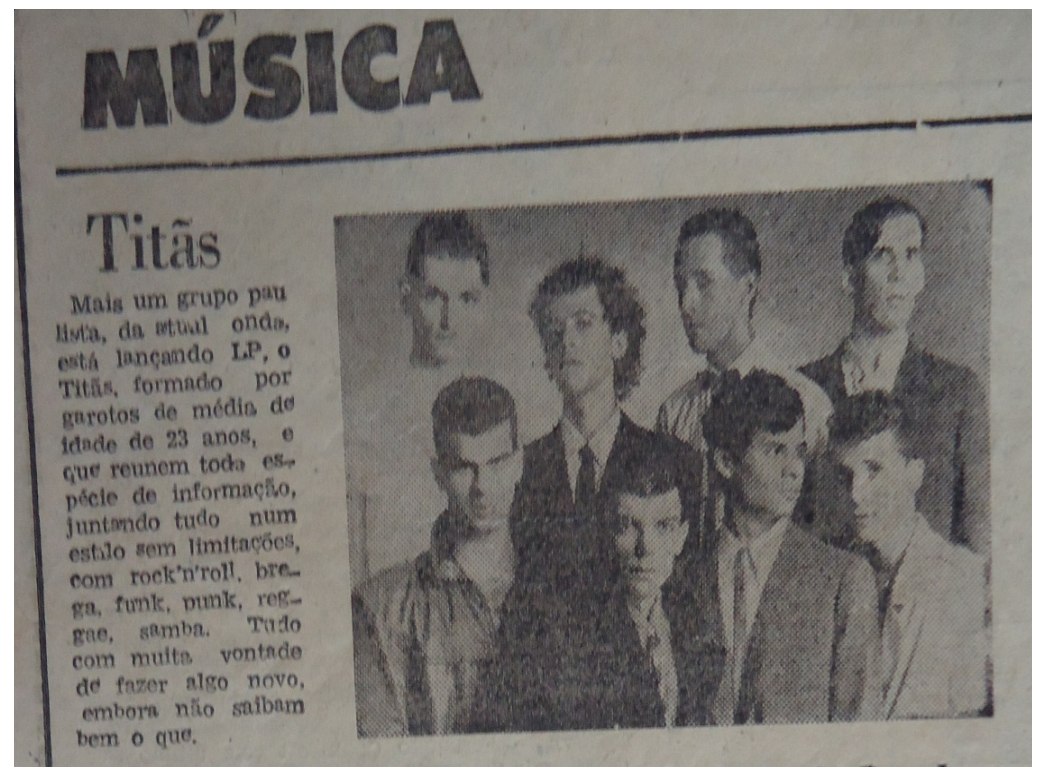

Figura 2. Jornal do Commercio, Caderno C, 5 set. 1984.

Apesar disso, outro mundo, suburbano, agitava-se invisível aos olhos do grande público consumidor. Para além do circuito universitário, da clas-
${ }^{43}$ RIBEIRO, Getúlio. Do tédio ao caos, do caos à lama: os primeiros capítulos da cena musical mangue - Recife, 1984/1991. Dissertação (Mestrado em História) - UFU, Uberlândia, 2007, p. 127.

44 "Samba de lado" (Chico Science \& Nação Zumbi), Chico Science \& Nação Zumbi. CD Afrociberdelia. Chaos/Sony, 1996.

${ }^{45}$ Ver RIBEIRO, Getúlio, op. cit. 
${ }^{46}$ Segundo o Mapa da violência publicado em 2012, a taxa de homicídios em Pernambuco, principalmente na Grande Região Metropolitana, girava em torno de 54 mortes para cada 100 mil habitantes, apresentando um crescimento médio de $4,7 \%$ ao ano. Esses números se referem especialmente aos anos de 1980 a 1994 . Cf. WAISELFISZ, Julio Jacobo. Mapa da violência 2012: a cor dos homicídios no Brasil. Rio de Janeiro-Brasília: Cebela/Flacso/ Seppir-PR, 2012.

${ }^{47}$ Exemplo disso se acha, entre muitos outros, em ALVES, Adjair, op cit., e CAMARGOS, Roberto. Rap e política: percepções da vida social brasileira. São Paulo: Boitempo, 2015.

${ }^{48}$ Ver ROSE, Tricia, op. cit.

${ }^{49}$ Ver, a propósito, o depoimento pessoal de BERMAN, Marshall. Nova Iorque chamando. ArtCultura: Revista de História, Cultura e Arte, v. 11, n. 18, Uberlândia, jan.-jun. 2009.

${ }^{50}$ Para a análise de outros fatores que estiveram na raiz do hip hop nos EUA, ver também BARRETO, Silvia Gonçalves Paes. Hip hop na Região Metropolitana do Recife: identificação, expressão cultural e visibilidade. Dissertação (Mestrado em Sociologia) - UFPE, Recife, 2004.

${ }^{51}$ Lourenço da Fonseca Barbosa, ou simplesmente Capiba, nasceu em Surubim, Pernambuco, em 1904, e faleceu no Recife em 1997. Foi compositor, folclorista, arranjador, historiador e cronista. Notabilizou-se, acima de tudo, com a criação de frevos para o carnaval pernambucano. É considerado patrimônio cultural do estado. Cf. SALDANHA, Leonardo Vilaça. Frevendo no Recife: a música popular urbana do Recife e sua consolidação através do rádio. Tese (Doutorado em Música) Unicamp, Campinas, 2008. se média, das casas de show, dos bares da orla marítima ou de clubes afins, nas periferias do Recife, Olinda, Camaragibe e Jaboatão dos Guararapes, jovens rompiam, até certo ponto, com a lógica nefasta de morticínio ${ }^{46}$ dos periféricos agarrando-se ao hip hop, em especial o break. Por sinal, embora sem querermos nos aventurar pelo estudo de manifestações juvenis que atravessaram as fronteiras da Grande Região Metropolitana do Recife, há inúmeros trabalhos ${ }^{47}$ que extrapolaram esses limites geográficos.

Como se sabe, o hip hop colou sua existência às crises, de diferentes ordens, que eclodiram em diferentes cidades. Como aponta Tricia Rose ${ }^{48}$, ele foi forjado nos Estados Unidos da América a partir dos processos de desmanche urbano de metrópoles como Nova Iorque ${ }^{49} \mathrm{e}$ Los Angeles, bem como dos cortes em verbas públicas e do sucateamento dos serviços nas áreas sociais, que impactaram duramente a qualidade de vida das áreas que concentravam a população mais pobre. ${ }^{50}$ Por isso todas as evidências indicam como berço do hip hop uma "terra arrasada". E é nessas "terras arrasadas" que podemos detectar a resiliência de setores da juventude ante essas ásperas realidades que os cercam.

\section{A dança maluca de Nova Iorque na terra de Capiba ${ }^{51}$}

Mais ou menos em 1981, do meio pro final de 1981, foi quando eu me deparei, pela primeira vez, com aquilo que ia definitivamente mudar minha vida, apesar de ser um fragmento. É, apesar de ser um fragmento, todo um universo, que eu viria depois conhecer. Foi o primeiro elemento do que nós conhecemos hoje como cultura hip hop que eu vi, foi o primeiro que me fez me apaixonar por essa cultura tão urbana e ao mesmo tempo tão humana. Na época eu já dançava funk e, modestamente, fazia parte da melhor geração daquela época [...] Quando vi aqueles caras dançando, aquela movimentação, com aquelas acrobacias, aquelas coisas, porra, aquilo ali bateu em mim de um jeito que, caramba, só pra ter uma ideia [...] Eu imagino no momento que eu vi aquela matéria na televisão, foi no Fantástico, no domingo, era umas oito, oito e pouco da noite, entrou o Cid Moreira com aquela voz: "Você, você não acredita, nós vamos mostrar daqui a pouco para você uma dança maluca, você num acredita no que esses jovens podem fazer". E eu, cara, dança maluca! Que é que esse cara vai mostrar? Cara, quando mostrou os caras fazendo movimentos, girando de costas, dançando poping, imitando um robô, cara, eu não acreditei naquilo, não. [...] Aquilo foi impactante demais pra mim: aquilo foi um impacto, foi um boom porque eu achei que tudo que eu tava fazendo era muito velho, muito antigo, num prestava. Na verdade, era a base de tudo que aqueles caras estavam fazendo, era o que eu queria fazer naquela época. [...] mostraram os caras dançando, bboys, os rockers e poppers, todo mundo ao mesmo tempo, até porque os caras que fizeram a matéria não tinham o menor conhecimento. [...] Quando eu vi em casa, disse pra mim: "é isso que eu quero fazer, eu quero fazer isso aí, eu agora vou fazer isso aí". Eu não deixei de dançar o funk; foi melhor ainda para mim [...] eu saí de casa correndo, feito um maluco, eu fui para um clube que tinha lá em Camaragibe, que na época era o único lugar que a gente tinha pra se divertir, que era chamado casa da música. A casa da música era um galpão que funcionava durante a semana como oficina e que nos finais de semana os caras esvaziavam ela e a galera alugava pra fazer festa. Cara, eu saí correndo da minha casa, eu corri mais ou menos uns dois a três quilômetros procurando meus amigos da época, e quando localizei os caras,"vem cá, vem cá, vem cá. Cara vocês não vão acreditar no que eu vi agora". "Que foi, que foi?" "Meu irmão, eu vi aquilo que vai ser a dança que a gente vai fazer, tudo o que vocês imaginaram". [...] Meu irmão, os caras que eram os amigos 
da época, o Nelson e o Onéssimo, compraram a ideia. Mal a gente sabia que tava começando um lance bem legal, não apenas em Camaragipe, mas pro Refice todo. Cara, é claro que na época a gente era mnoleque e só queria dançar, nem imaginava que um dia ia ter pessoas da universidade interessadas na nossa dança, que no começo era muito despretenciosa. Por isso eu sempre falo como o hip hop começou e se desenvolveu no Recife. Depois, cara, nós começamos a levar aquilo a sério mesmo, ensaiando todo dia, correndo atrás de fita cassete e vídeo de dança, tanto é verdade que, no lançamento dos filmes Beat street e Break dance, eu e os meninos já tínhamos uma noção bacana dos movimentos. E quando a gente se deu conta já tava batalhando com as outras gangues de dança no centro da cidade, inclusive com a Legião Hip Hop de Chico e Jorge. ${ }^{52}$

A história do movimento hip hop, particularmente o break no Recife, confunde-se com a trajetória artística de Fábio Luna. ${ }^{53}$ Tal como no caso do MangueBit ${ }^{54}$, a capital foi o palco preferido da juventude breaker, arrastando, por assim dizer, os municípios vizinhos e o contingente humano de suas periferias para as manifestações artísticas que nela ganhavam destaque. Mas o que nos interessa ressaltar, aqui, inicialmente, é, como se evidencia no depoimento de DJ Spider, o papel relevante dos meios de comunicação massivos ao porem em circulação, mundo afora, a novidade trazida de Nova Iorque.

O hip hop deu verdadeiro salto do underground para os noticiários e os periódicos, e o público em geral foi impulsionado pelas produções fonográficas ${ }^{55}$ e cinematográficas ${ }^{56}$ contribuíram decisivamente para a proliferação dos praticantes do break e, em consequência, aproximaram os jovens brasileiros do movimento hip hop idealizado por Afrika Bambaataa e DJ Cool Herc ainda no final dos anos 60, nos Estados Unidos. Na imprensa recifense era possível recolher os ecos dessa explosão. Muito se falou dela, notadamente desde o segundo semestre de 1984.

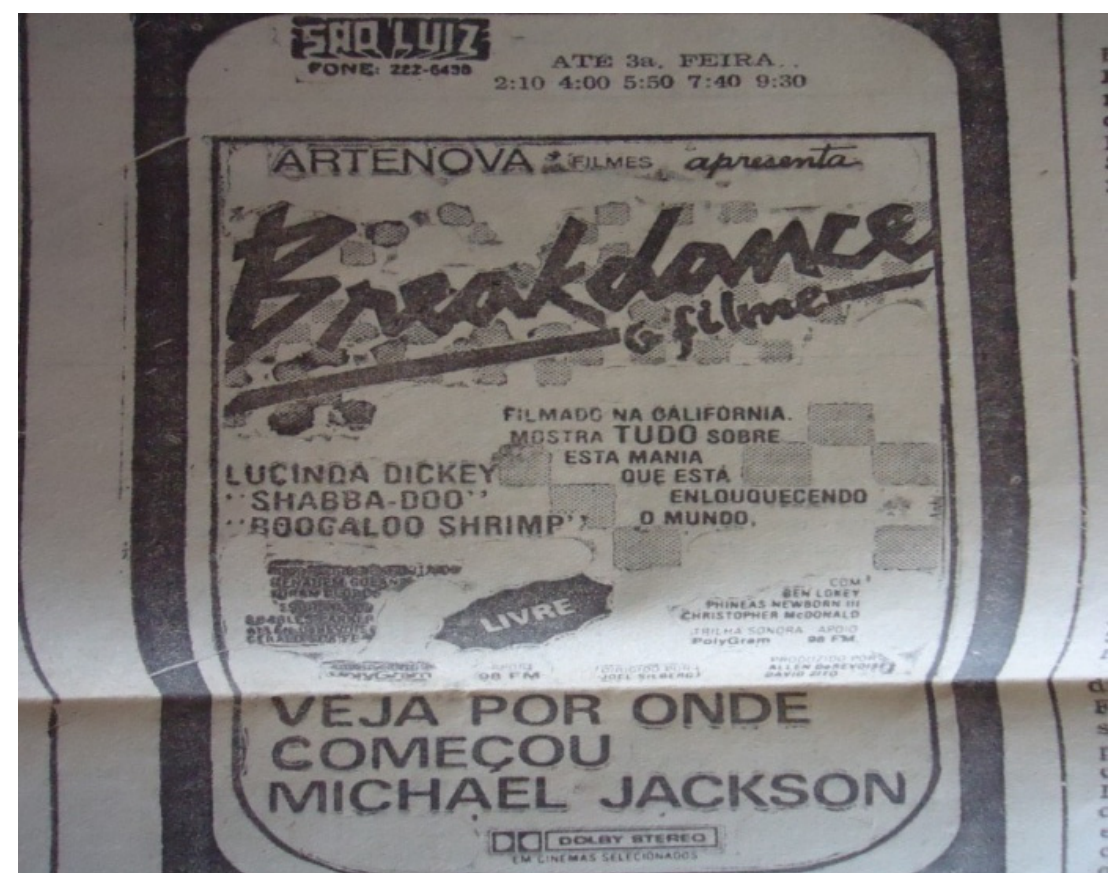

Figura 3. Jornal do Commercio, Caderno C, 19 set. 1984.

O Brasil e sua enorme periferia urbana acolheram o hip hop como cultura, além de incorporar a ele traços característicos do nosso país, como

${ }^{52}$ Entrevista concedida por Fábio de Morais Luna (DJ Spider), op. cit.

${ }^{53}$ Fábio de Morais Luna ou DJ Spider é tido por muitos praticantes do break no Recife como o fundador do movimento na capital pernambucana. Colecionou diversos títulos nas disputas de dançarinos ao longo da sua carreira como breaker nos anos 1980 e 1990. Atualmente é funcionário do Banco Santander e organizador de festivais de break em todo o Brasil.

${ }^{54}$ Em nossa pesquisa acerca do MangueBit, que se estende de 2005 até esta data, constatamos que, mesmo que os artífices não sejam oriundos da capital, a cidade é vivenciada como um palco de possibilidades de alavancar suas carreiras artísticas, como aconteceu com Chico Science \& Nação Zumbi (apenas o guitarrista Lúcio Maia era do Recife, enquanto, o restante da banda era proveniente de Olinda). Isso se verificou igualmente com o Mundo Livre S/A: a banda era integrada por músicos de Jaboatão dos Guararapes. Cf. NASCIMENTO, Francisco Gerardo Cavalcante do. MangueBit: diversidade na indústria fonográfica brasileira na década de 1990. Dissertação (Mestrado em História) - Uece, Fortaleza, 2011.

${ }^{55}$ Notadamente o LP Break time. RGE, 1984.

${ }^{56}$ Beat street: loucura do ritmo. EUA, 1984. Dir.: Stan Lathan. Orion. Break dance: breakin. EUA, 1984. Dir.: Joel Silberg. Cannon Group/Golan Globus. 
${ }^{57}$ Cf. ROSE, Tricia, op.cit., p. 192-195.

${ }^{58}$ Partido alto. Brasil, 1984. Rede Globo de Televisão. Dir.: RobertoTalma, Jayme Monjardim, Carlos Magalhães, Luís Antônio Piá e Helmar Sérgio. Disponivel em <http://memoriaglobo. globo.com/programas/entretenimento/novelas/partido-alto/ galeria-de-personagens.htm>. Acesso em 27 set. 2017.

59 "Enredo do meu samba" (Dona Yvone Lara e Jorge Aragão), Sandra de Sá. LP Partido alto - nacional. Som Livre, 1984. elementos do samba, embolada, capoeira e maculelê, presentes em alguns trabalhos autorais. Nessa linha, Tricia $\operatorname{Rose}^{57}$ acentua que o hip hop se reveste de um caráter híbrido e assimila, entre outros, aspectos da cultura negra e as novas tecnologias. Tal fato, aliado à tomada de consciência do lugar social desses jovens, permitiu-lhes representar seus espaços coletivos de uma maneira que a violência, a desigualdade, o próprio crime fossem problematizados e percebidos como vetores de uma estigmatização social dos periféricos.

Contudo, a despeito de o hip hop se espalhar por lugares diferenciados, a projeção do movimento foi bem mais intensa e visível no Sudeste brasileiro. Para tanto a televisão jogou um papel considerável, ela foi um dos primeiros destinos dos dançarinos de break. Foi o que se viu, por exemplo, na abertura da novela Partido alto ${ }^{58}$, da Rede Globo de Televisão, em 1984. Nela breakers e passistas de samba dançavam ao som da canção "Enredo do meu samba" ${ }^{\prime 59}$, interpretada por Sandra de Sá.

A época de pouca informação foi se dissipando aos poucos. As primeiras gangues de dança foram surgindo e se fortalecendo, dentre elas, em São Paulo, Nação Zulu, Street Warriors, Crazy Crew, Back Spin, Jabaquara Breakers; em Brasília, equipes como Eletric Bugaloo, e, no Recife, The Brothers of the Breakers, Recife City Breakers, Legião Hip Hop, The Dragons, Banana Breakers, UBI, Rádio Break CIA, Rock Master Crew e Geração Camaragibe. O novo, nessa área, se instalava de vez.

De todo modo, os primeiros anos do break no Grande Recife podem ser considerados como um período de mútuo conhecimento. Primeiramente, havia um desconhecimento dos elementos constitutivos do movimento hip hop por parte dos praticantes do break com relação aos produtores culturais, empresários e comerciantes. O impulso inicial do break se ligava à sua percepção como uma alegoria, uma dança de movimentos plásticos, nada relacionada a um viés contestatório. Logo em seguida, algumas apresentações, eventos e até mesmo contratos com lojas foram efetivados ainda nos primórdios do break recifense. Nesse contexto despontou The Brothers of the Breakers, da qual Fábio Luna foi fundador e integrante, considerada por diversas fontes como a primeira gangue de dança de Pernambuco.

Esse protagonismo da The Brothers of the Breakers rendeu-lhe alguns frutos já na primeira metade da década de 1980, como, por exemplo, o contrato com a loja Drops, do Shopping Center Recife, especializada em moda surf wear, além de apresentações esporádicas em estabelecimentos comerciais sem nenhuma vinculação com o estilo break ou nem sequer voltados para o público juvenil, como no caso da loja Chi Chi Babys, direcionada ao público infantil.

Há um fato significativo nessa cronologia do break no Recife que de certa forma relativiza a ideia de boom logo após os lançamentos de Beat street, Break dance e Break time em 1984. Referimo-nos à a realização do primeiro campeonato de break na cidade, promovido pelo extinto canal de televisão Manchete, em 1983. Ainda nesse mesmo ano a The Brothers of the Breakers passou a se chamar Rock Master Crew, segundo consta, a primeira equipe a incorporar o nome crew, o que nos indica que já começava a ter conhecimento a respeito das siglas, denominações e finalidade do movimento hip hop.

Uma das primeiras rodas de break, senão a primeira do Recife, ocorreu em 1984 na Rua 7 de Setembro. Todavia, é preciso ressaltar que 
as primeiras disputas estão associadas aos lançamentos cinematográficos anteriormente comentados por nós. Nesse sentido, 1984 é emblemático para o break na capital pernambucana, tanto quanto para nossa pesquisa, particularmente, porque se registrou nesse ano a formação de diversas gangues de dança ${ }^{60}$ no Grande Recife. O movimento difundiu-se pela cidade, principalmente pela Rua do Hospício, Rua 7 de Setembro e Parque 13 de Maio, na região central, porém uma gangue de dança merecerá nossa atenção especial, a Legião Hip Hop, que representa o período, por assim dizer, gestacional de Jorge dü Peixe e Chico Vulgo (Science) no universo do hip hop.

\section{A Legião Hip Hop: a periferia de Olinda em ebulição}

Em 83, 84 conheci Chico ali na Associação de Moradores de Rio Doce, na quarta etapa, onde existia todo final de semana funk, soul e música de todo mundo, diáspora africana se espalhando ali e tal. Tinha uma noite de som, quando a gente era bem mais novo. Na terceira etapa tinha um clube de moradores, uma associação de moradores; eles tinham um concurso de black music, dança black, chamava na época, e tinha grandes dançarinos de black na época que imitavam, ficavam na sombra de James Brown. Tinha um cara que era o Mister $X$, que se fantasiava, e todos deixando o cabelo meio afro, usava umas bengalas, cavalo de aço, aquele troço nojento de uma maneira muito louca, e o som sempre esteve em primeiro plano, primeira instância. E depois dessa época, 83, cara, Chico trabalhava numa clínica radiológica de Recife entregando carteira de saúde. O pai dele era enfermeiro, seu Francisco, depois veio a se candidatar e virou vereador em Olinda e tal. Conheci Sérgio Mofado, que era um cara que tinha dois expedientes. Ele andava com a gente, brincava e tal. Descobri algum tempo depois, o cara era gente finíssima, num sabia o que é que ele fazia; ele gostava muito de som e certa vez Sérgio Mofado, eu tava dançando no clube lá e tal, e tinha umas rodinhas de funk, eu me aproximava da dança do break, já era break, e a galera meio que, porra, era o grupo deles fechado, beleza, e chegava quebrando coisa e tal [...] Isso foi 82, 83, eu acho, cara, 83. Depois desse conhecimento eu já praticava o break em 83, já. No dia seguinte, Sérgio Mofado, "vou te apresentar um amigo meu, vamo ali no centro comigo, lá na Rua Direita", pá, pá, pá. Subimos uma escada, uma sala vazia com um birô no canto, tava Chico sentado lá. "Ah, tu é aquele boy cabeludo que tava tentando dançar com a gente ontem. Tu tava lá ontem, nem te vi, véi, aquela greia toda". Esse cara fazia rap, cara, e Chico começou a bater no birô, tuc, tsi..., do jeito que era uma bateria eletrônica, do jeito que tivesse uma ligação maior. Então começou a escrever timidamente as primeiras letras de rap ali, cara, e na sequência eu fiz uma letra com Chico. Chamava "Negros", e a partir daí, né?, criou-se uma amizade, a gente se aproximou mais e começou a fuçar vinil, a virar sebo, rato de sebo e tal. Ali a gente vendia livro da coleção da estante que os pais compravam, coleção Barsa, aqueles troços todos, chegava no sebo pra trocar por vinil, cara, e a coleção da estante diminuindo e tal [risos]. Era engraçado isso. Lembro que na época a gente pegou um disco que foi muito foda, Break in walk ${ }^{61}$, de Malcom Mc Laren. De Malcom Mc Laren, cara! Ele tinha ido pra África e gravou com os Zulus e tal. E aquilo deixou Chico muito chapado. Isso é um disco de peso pra gente. Tem um gravadorzão na capa assim, bem enfeitado ali e tal, com dois chifres laterais, e pra gente aquilo era uma imagem forte do hip hop. Na mesma época teve ali um clássico, Afrika Bambaataa $e$ Sound Sonic Force, cara, aquele disco, aquela música... Se não fosse aquele disco e o Kraftwerck, aquilo é calçado no Kraftwerck. Então, música eletrônica e
${ }^{60}$ Foram elas Recife City Breakers, Legião Hip Hop, The Dragons, Banana Breakers, UBI, Rádio Break CIA, Rock Master Crew e Geração Camaragibe.

${ }^{61} \mathrm{Na}$ realidade, trata-se do disco Soweto/Zulu's on a time bomb, de Malcom McLarem, gravado pela Southern African Music em 1983. 
${ }^{62}$ Entrevista concedida por Jorge dü Peixe a este pesquisador em Olinda, em 12 jan. 2015.

${ }^{63}$ Fundada em 1973 por Afrika Bambaataa, a Zulu Nation visava ajudar desde então os jovens afetados pela violência associada às gangues. A "ajuda", no caso, era proporcionada por meio da cultura hip hop, apoiada inicialmente em três elementos fundamentais: break, discotecagem e graffiti. Posteriormente, foram agregados os DJs Kool Herc e Grand Master Flash, consolidando o movimento cultural hip hop mediante a integração dos seus cinco elementos básicos: MC, DJ, bboy, graffiti e o conhecimento, popularizando definitivamente o movimento. Cf. BASTOS, Pablo Nabarrete. Ecos de espelhos: movimento hip hop no ABC paulista: sociabilidade, intervenções, identificações e mediações sociais, culturais, raciais, comunicacionais e políticas. São Paulo: Tese (Doutorado em Ciências da Comunicação) - USP, São Paulo, 2008, p. 85-91.

${ }^{64} \mathrm{O}$ Centro Daruê Malungo atua há mais de vinte anos no bairro Chão de Estrelas, periferia do Recife, na promoção da educação e valorização da cultura. Foi lá que Chico Science travou o primeiro contato musical com o grupo Lamento Negro, de Gilmar Bola Oito, que em pouco tempo viria a compor o naipe de tambores da Nação Zumbi. esses elementos da África que se espalharam pelo mundo foram o que fomentou o hip hop. Hip hop tem muito do reggae. Num sei se você percebeu, mas a gente pode fazer um paralelo com os jamaicanos que fomentaram o sound system na Inglaterra no começo daquilo ali e se manifestou de um jeito na Inglaterra e de outra maneira nos Estados Unidos. O crash vem disso; o crash fazia calçado no rock and roll com a música negra. E nessa época a gente continuou dançando, criou-se a Legião Hip Hop. Tinha um pessoal de Camaragibe, e o Fábio Aranha é um cara que mostrou disco de hip hop pra caramba pra gente. Aliás L Cool Jay, Curtis Blow, Dis Marky. [...] E aí, cara, o centro de Recife começou a fomentar tudo isso, tudo isso nasceu realmente do hip hop, a ideia do Nação Zumbié meio calçada na Nação Zulu. ${ }^{62}$

Pelas palavras de Jorge dü Peixe, notamos que a música esteve presente entre os jovens olindenses bem antes do MangueBit. Entre outros, havia dois garotos que nasceram no Recife, cresceram em Olinda e desde cedo ataram seus imaginários à Black music e à cultura popular de Pernambuco.

A transição da infância para a adolescência foi a fase das descobertas musicais para o jovem Francisco de Assis França. Os bailes black e funk foram a porta de entrada para ele. Seu reduto, alguns clubes de Olinda como o Clube Ferroviário e o Clube dos Rodoviários. Nessas primeiras investidas nos bailes reinavam artistas como James Brown, Charles Wright, Kurtis Blown, George Clinton, The Funkadelics, influências musicais preponderantes que o seguiriam por toda sua breve carreira artística.

A Legião Hip Hop seria uma experiência basilar na formação de quem, alguns anos mais tarde, viria a articular a movimentação multicultural MangueBit. As práticas culturais de Chico Vulgo, iniciadas ao lado dos amigos de adolescência Sérgio Mofado e Jorge dü Peixe, o piso encerado que era levado à praça da Vila Olímpica na terceira etapa de Rio Doce, tornaram-se referências marcantes para eles no universo hip hop. Umas das características peculiares da Legião Hip Hop, apontadas por nossos depoentes, era o número elevado de integrantes que a gangue possuía. Nas disputas organizadas no centro do Recife, notava-se um caráter agregador oriundo das iniciativas de Chico Vulgo. Isso evidencia uma ideia de "coletivo" sintonizada com os ideais propagados pela Zulu Nation $^{63}$, que estiveram na base da Legião Hip Hop e se estenderam à Orla Orbe, Bom Tom Rádio, Loustal, Lamento Negro, em parceria com o Daruê Malungo ${ }^{64}$, e, finalmente, à Nação Zumbi (bandas das quais Chico tomou parte)

Em meio à vida por vezes efêmera das gangues de dança do Grande Recife, há de se considerar que a Legião Hip Hop teve uma existência relativamente longa, comparada às suas congêneres. TheDragons, por exemplo, liderada pelo porto-riquenho Erick K, sediada no município de Jaboatão dos Guararapes, durou poucos meses. Bailando entre a terceira etapa de Rio Doce, a Praça da Vila Olímpica e a área central do Recife, os jovens breakers Chico Vulgo e Jorge dü Peixe faziam uma apropriação do espaço público, principalmente entre 1984 e meados de 1985, período eminentemente breaker da Legião Hip Hop, que corresponde à primeira fase do grupo. 


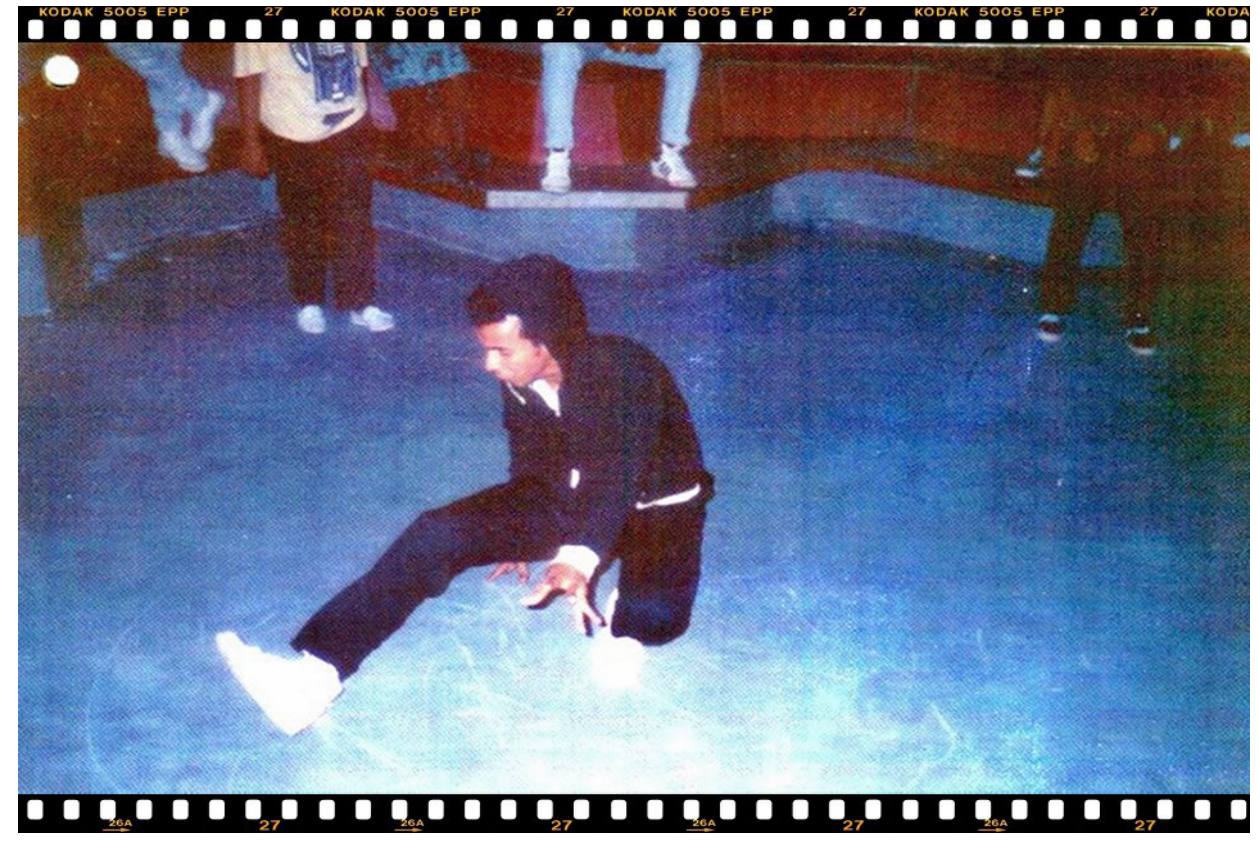

Figura 4. Chico Vulgo (futuro Chico Science) dançando break na década de 1980.

Em um segundo momento, a Legião Hip Hop diversificou suas atividades entre 1985 a 1987. Jorge dü Peixe enveredou pelo graffiti, traço característico na formação artística do músico, que o acompanha até os dias atuais e lhe rendeu inclusive trabalhos em capas de CDs da Nação Zumbi e Mundo Livre S/A. ${ }^{65}$ Com Chico Vulgo, tal diversificação no âmbito do hip hop foi ainda maior. Ele abraçou a prática do rap com sua poesia rimada e a temática da contestação social já nas suas primeiras canções ${ }^{66}$, que foram gravadas posteriormente nos dois únicos álbuns que contaram com a participação do músico.

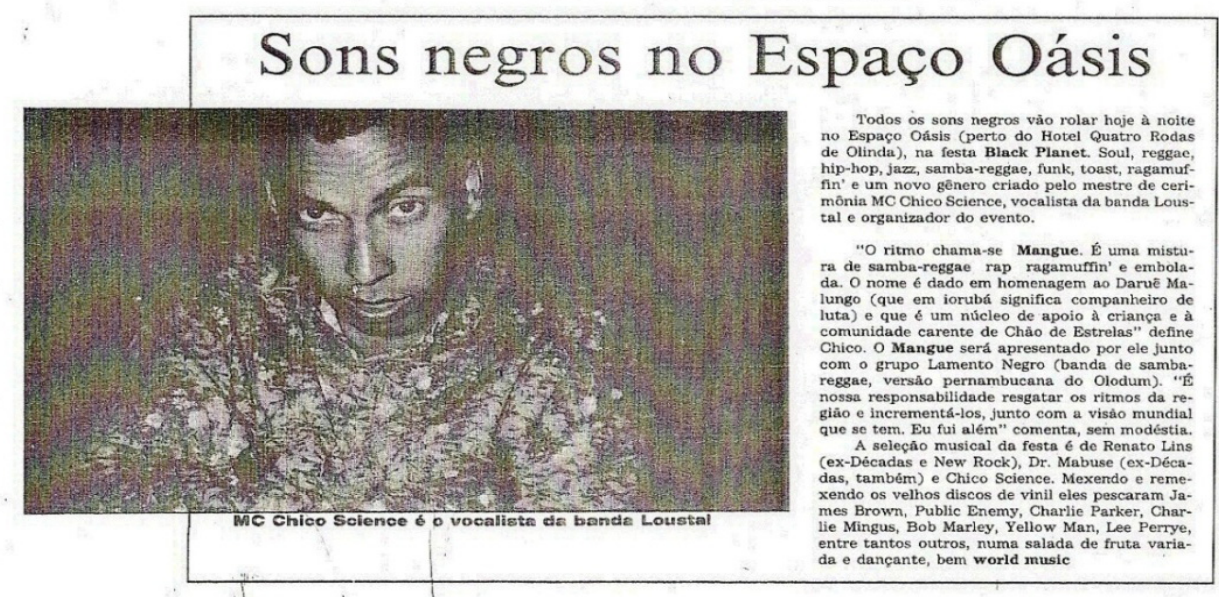

Figura 5. Jornal do Commercio, Caderno C, 1 jun. 1991.

Esse mergulho no rap, a nosso ver, foi um divisor de águas na carreira de Chico. A partir daí ele assumiu os vocais, ou melhor, passou a ser "voz ativa" 67 em todas as bandas das quais participou, seja na Orla Orbe, Bom Tom Rádio, Loustal, Chico Science e Lamento Negro e Chico Science \& Nação Zumbi. As composições de Chico Science possuíam alma, no sentido literal da palavra, expressa na voz e na interpretação rap, como na mencionada música "Negros", feita em parceria com Jorge
${ }^{65}$ Exemplo é o $\mathrm{CD}$ da banda Mundo Livre S/A, Combat samba. Deck Disc, 2008.

${ }^{66}$ São elas: "Banditismo por uma questão de classe" (Chico Science), Chico Science \& Nação Zumbi. CD Da lama ao caos, op. cit., "Rios, pontes e overdrives" (Chico Science), Chico Science \& Nação Zumbi., idem, e "Maço" (Chico Science), Chico Science \& Nação Zumbi. CD Afrociberdelia, op. cit.

${ }^{67}$ Consideramos o termo adequado à poética e ao tom crítico injetado nas vozes da rap music. Em linhas gerais, o historiador Roberto Camargos sustenta que o rap exprime, em larga medida, a consciência crítica da periferia para a periferia. "Voz ativa é, particularmente, um brado antirracista, atento às dificuldades enfrentadas pelos negros brasileiros no dia a dia (até porque seus autores também as vivenciam)." Cf. OLIVEIRA, Roberto Camargos de. Periferia com o poder da palavra: a poética dos rappers brasileiros. Tese (Doutorado em História) - UFU, Uberlândia, 2016, p. 15. 
${ }^{68}$ Idem, ibidem, p. 30.

${ }^{69}$ BENJAMIN, Walter. Obras escolhidas III: Charles Baudelaire, um lírico no auge do capitalismo: São Paulo. Brasiliense, 1989 , p. 35.

${ }^{70}$ ZUMTHOR, Paul. Performance, recepção e leitura. São Paulo: Cosac Naify, 2014, p. 30.

${ }^{71}$ OLIVEIRA, Roberto Camargos de, op. cit., p. 31.

${ }^{72}$ O Population Crisis Commitee, sediado em Washington (EUA), caracterizou Recife como a quarta pior cidade do mundo para se viver, levando em conta, entre outros indicadores, dados como o alto índice de violência urbana per capita (o maior do Brasil), altas taxas de desemprego, insuficiência de saneamento básico e condições precárias de moradia para a maioria da população. Cf. informação disponível em <ttps://www.popline.org/ node/573872>. Acesso em 27 set. 2017.

${ }^{73}$ A ideia de uma palavra escrita ser transcendida pela vocalidade se afina com as proposições de Zumthor, para quem a voz não é meramente uma palavra escrita oralizada. Ela põe em circulação uma ação oral-auditiva num jogo em que a sonoridade, o ritmo e os elementos visuais convidam o leitor (ou o ouvinte) não somente para a leitura (ou a audição), mas também para interagir corporalmente com a obra. Cf. ZUMTHOR, Paul. A letra e a voz: a "literatura medieval". São Paulo: Companhia das Letras, 1993. Nessa linha de preocupação, ver PARANHOS, Adalberto. A música populare a dança dos sentidos: distintas faces do mesmo. ArtCultura, n. 9, Uberlândia, jul.-dez. 2004. Neste artigo são analisados registros fonográficos em que a interpretação (quer vocal ou instrumental) empresta sentidos diferentes a canções, que, de resto, são artefatos culturais que não carregam em si mesmos significados unívocos, congelados no tempo e no espaço.

${ }^{74}$ Trecho inicial de "Um passeio no mundo livre" (Chico Science, Dengue, Lucio Maia, Gira, Jorge dü Peixe e Pupilo), Chico Science \& Nação Zumbi. CD Afrociberdelia, op . cit.

${ }^{75}$ Fonte: Arquivo pessoal do DJ Elcy Oliveira. dü Peixe nos tempos de Chico Vulgo. A propósito, Roberto Camargos de Oliveira salienta que, "no caso do rap, o compositor e o intérprete geralmente se confundem". ${ }^{68}$ Não seria para menos: o ritmo, o estilo são extensões das suas vidas, espetacularizam, pelo canto, a realidade. $\mathrm{Na}$ voz de Chico Science e sua poética, há o Recife dos ambulantes e transeuntes, junto aos quais o poeta dos mangues sente-se acolhido, isto é, entre os seus. Vislumbra-se em suas criações a cidade do flâneur, na qual "a rua se torna moradia para o flâneur" ${ }^{69}$ Nela o homem que perambula pela urbe, sua canção, a presença da voz, ou mesmo sua ausência, dão sentido à performance do indivíduo.

Na ótica de Zumthor, a "performance, eu diria que ela é o saber ser. É um saber que implica e comanda uma presença e uma conduta". ${ }^{70} \mathrm{E}$ é exatamente dentro do quadro de palidez dos dias e do negrume das noites que configuram as vivências dos jovens de periferia que, apesar dos pesares, "com suas músicas, os rappers enquadram a vida social e dela pintam uma imagem diferenciada [... com] sua poética - por vezes ácida e indigesta" ${ }^{71}$

Chico foi um observador, leitor e tradutor da metrópole depauperada. ${ }^{72} \mathrm{~A}$ ideia de modernidade atravessava suas composições (uma modernidade capitalista extremamente contraditória, logo se vê, assentada numa brutal desigualdade econômico-social). Esse combustível urbano alimentava os versos do jovem olindense. $\mathrm{O}$ texto escrito e fixado por ele foi transcendido pela sua voz possuidora de movimento ${ }^{73}$ e que o tornava presente com sua performance.

\section{Do break ao rock: um passo à frente}

E aí deu-se um passo à frente: da existência da Legião Hip Hop à Orla Orbe. E "um passo à frente e você não está mais no mesmo lugar". ${ }^{74} \mathrm{~A}$ carga simbólica destas palavras sinaliza o caminho trilhado por Chico, que foi Vulgo no início breaker e rapper, e, depois, Science como vocalista e líder da banda Nação Zumbi. O salto da dança para a voz, em 1987, conduziu o jovem breaker pelo mundo das bandas. Em sua primeira formação, com Chico Vulgo nos vocais, Helder no baixo, Fernando na guitarra e Vinicius na bateria, a banda Orla Orbe era composta exclusivamente por moradores de Rio Doce, com exceção de Lúcio Maia, que, oriundo do bairro Casa Caiada, em Olinda. foi incorporado ao grupo mais adiante.

Quinta-feira, 2 de março de 1989, às 22 horas, a Boite Misty, no centro do Recife, conhecido reduto GLS da classe média, recebeu uma festa nada convencional para as casas de shows da capital pernambucana na época, à base de bandas e DJs desconhecidos para a grande maioria do seu público habitual. O spot de divulgação dizia: "Atenção galera, vem aí a primeira festa hip hop do Recife. Você estará em contato com o mundo dos bboys, DJs, rappers, grafiteiros e mais as bandas Orla Orbe, KZF e DJ Spider, com muito hip hop pra você dançar. É de rachar o assoalho. Vamos lustrar o piso. Dia 02 de março, quinta-feira, às 22 horas, na Misty. Hip hop, a arte não para". ${ }^{75}$

Fábio Luna assegura que essa foi a primeira festa realizada no Recife em que os organizadores e a temática eram pertencentes ao contexto do hip hop. Conforme ele, "foi o primeiro evento, já assim no final dos anos 80 , que mostrou que cultura também era com a gente, porque a gente tinha passado por toda a década de 1980 vivendo a cultura e se movimentando" ${ }^{76}$ 
A inserção desses jovens em locais improváveis para as suas apresentações demonstra, em certa medida, o seu poder de articulação entre universos que, em princípio, são distintos: periferia e região nobre, classe média e periféricos, hip hop e outros estilos. Tal festa foi, ao que tudo indica, a primeira apresentação de hip hop para o grande público na capital, embora antes disso houvessem acontecido outras no centro da cidade, em Rio Doce, ou mesmo em encontros esporádicos em Olinda, os quais envolviam campanhas eleitorais, festivais de cultura e competições de esporte nas comunidades.

O Rio Doce consistiu no local das primeiras investidas artísticas de Jorge dü Peixe e Chico Vulgo. Nas suas apresentações, os amigos e os familiares compunham a maior parte do público. O bairro era seu pedaço ${ }^{77}$, o lugar em que esses jovens músicos estabeleciam suas relações mais caras desde sua a entrada no mundo da música, vivenciando suas ambiências na periferia do Grande Recife. Mas, após o surgimento da Orla Orbe, eles expandiram suas atuações, irradiaram suas práticas culturais além das fronteiras periféricas de Olinda, alterando, a seu modo, a geografia cultural da Região Metropolitana do Recife. Traçava-se, sob determinado aspecto, um novo trajeto naquele meio, se entendermos por trajeto uma noção que se aplica "a fluxos recorrentes no espaço mais abrangente da cidade e no interior das manchas urbanas". ${ }^{78}$

Artigo recebido em fevereiro de 2018. Aprovado em maio de 2018.

\footnotetext{
${ }^{76}$ Entrevista concedida por Fábio de Morais Luna (DJSpider) a este pesquisador, op. cit.

${ }^{77}$ Magnani caracteriza o pedaço como "aquele espaço intermediário entre o privado (a casa) e o público, onde se desenvolve uma sociabilidade básica, mais ampla do que a fundada nos laços familiares, porém mais densa, significativa e estável do que as relações formais e individualizadas impostas pela sociedade". MAGNANI, José Guilherme Cantor. Os circuitos dos jovens urbanos. Tempo Social: Revista de Sociologia da USP, v. 17, n. 2, São Paulo, 2005, p. 178

${ }^{78}$ Idem.
} 